\title{
A Study of Financial Acquisition Risk Identification and Prevention
}

\author{
Qingxia Zhang \\ Management School, Jinan University, Guangzhou, China \\ Email: sophiascut@163.com
}

How to cite this paper: Zhang, Q.X. (2017) A Study of Financial Acquisition Risk Identification and Prevention. Modern Econo$m y, 8,475-483$.

https://doi.org/10.4236/me.2017.84035

Received: February 27, 2017

Accepted: April 4, 2017

Published: April 7, 2017

Copyright (C) 2017 by author and Scientific Research Publishing Inc. This work is licensed under the Creative Commons Attribution International License (CC BY 4.0).

http://creativecommons.org/licenses/by/4.0/

\begin{abstract}
In this paper, the financial risk of Ping An Insurance (Group) Company of China, Ltd. acquisition of Shanghai Jahwa United Co., Ltd is divided into the target enterprise risk assessment risk, financing risk and uncertainty of future earnings according to $\mathrm{M} \& \mathrm{~A}$ links. The study finds that the target enterprise value assessment under market approach is close to the transaction price; the financing risk can be divided into long-term risk and short-term risk; Uncertainty of future earnings arises from the volatility of the stock price caused by the uncertainty of the target enterprise. To reduce these three risks, this study suggests that $\mathrm{M} \& \mathrm{~A}$ companies adopt a variety of methods to comprehensively assess the value of the target enterprise, rationally design the financing plan and pay close attention to the target business operation.
\end{abstract}

\section{Keywords}

Financial Acquisition, Risk Identification, Risk Prevention

\section{Introduction}

Compared with the strategic acquisition, the financial acquisition does not involve the later part of the business integration, that is, the two sides remain independent, and the financial risk is relatively easy to measure, so this study selected financial acquisition for case analysis. Then how to measure the financial risk involved in mergers and acquisitions? This article specifically calculates and analyzes through the Ping An Insurance (Group) Company of China, Ltd. (China Ping An as below) acquisition of Shanghai Jahwa United Co., Ltd (Shanghai Jahwa as below).

The contribution of this research lies in the exact calculation of the financial risk involved in mergers and acquisitions through the specific case data, which is not only the practice of $\mathrm{M} \& \mathrm{~A}$ financial risk research, but also provides a new way for the financial risk measurement. 
The structure of this paper is as follows: the second part is about the classification of financial risk related to $\mathrm{M} \& \mathrm{~A}$, including the definition of $\mathrm{M} \& \mathrm{~A}$ financial risk, the definition of financial risk and the general calculation method. The third part is the case study of Ping An acquisition of Shanghai and specific financial risk analysis; the fourth part is the conclusion and recommendations.

\section{Literature Review and Theoretical Analysis}

\subsection{Literature Review of M \& A Financial Risk Classification}

Healy argues that corporate risk of mergers and acquisitions refers to the possibility that failed mergers and acquisitions lead to a series of terrible consequences such as lower corporate market value and rising management costs [1]. Jeffrey. C. Hooke argues that the financial risk of $M \& A$ is the financial and debt risk that the firm intends to complete the financing and debt repayment through the debt financing [2]. Deng Xianxue argues that, firstly, there are environmental risks, information asymmetry risk and valuation risk in the preparation stage of $M \& A$ with the steps of mergers and acquisition as the order. Secondly, there are financing risks and payment risks in the decision-making stage of $\mathrm{M} \& \mathrm{~A}$. Finally, there is integration risk in the integration stage of $\mathrm{M} \& \mathrm{~A}$ [3]. Li Jintian argues that the main financial risks of $\mathrm{M} \& \mathrm{~A}$ arise from financial activities such as value assessment and financing payments [4]. Therefore, financial risk is inevitable in all aspects of $\mathrm{M} \& \mathrm{~A}$, which is essentially a value risk.

Based on the domestic and foreign research, this paper divides the financial risk of $\mathrm{M} \& \mathrm{~A}$ into the target enterprise pricing risk and the investment income uncertainty risk according to the $\mathrm{M} \& \mathrm{~A}$ links.

\subsection{Literature Review of the Enterprise Value Assessment}

$\mathrm{Hu}$ Xuanneng thinks that the price-earnings ratio method is a simple and effective method for pricing the M \& A enterprises [5]. Specifically, it can evaluate the market value of the $M \& A$ enterprise's own earnings by referring to the price-earnings ratio of the enterprises in the same industries, and to evaluate the market value of $\mathrm{M} \&$ A enterprises' own income growth ability, but this method is more suitable for the market value evaluation of listed companies. Song Xiaoshan study that different purposes of mergers and acquisitions should use different pricing methods, commonly used pricing methods are cost approach, market approach, income approach and real options approach [6]. If the merged company does not continue to operate, the cost method can be used to assess liquidation value. If the merged company continues to operate, the market method or the income method can be used to measure the value. Ge Qingbing classifies the value of the merged enterprise as net worth of net assets, market value and net present value of future cash flow [7].

Based on the above research, this paper uses the market method to evaluate the target enterprise value in order to analyze whether the $\mathrm{M} \& \mathrm{~A}$ has the wrong pricing. 


\subsection{Literature Review of M \& A Financing Risk}

Liu Bei thinks that the cost of internal financing is very low but the source is limited through cost analysis [8]. Debt financing cost is low, the procedure is simple, the way is more mature, but it will bring greater financial risk to the enterprise, increase the enterprise's asset-liability ratio, and reduce the stock price. Equity financing maturity is not fixed, but takes a long time, which will make the company's share price is expected to overestimate or even be acquired. Feng Qi argues that the interest repayment ratio is a multiple of the interest that should be paid for the project and the interest that the project borrows should pay [9]. If the cash increment of the project is higher than the interest expense, the reimbursement risk is small.

In the case of this paper, the debt financing and cash payment is adopted. Therefore, this paper constructs a cash flow increment analysis model based on the definition of the risk of reimbursement to analyze whether there is a risk of capital breakage in the case.

\subsection{Literature Review of Uncertainty Risk of M \& A Investment Return}

Zhang Junrui compared the three concepts of income, which explain the earnings of the book is the money earned by the enterprise, rather than the cash earned by the enterprise, is a virtual income [10]. This paper collects the stock price data after Shanghai Jahwa is acquired in different periods, and calculates the book proceeds from Ping An of China. By observing the fluctuation of book proceeds to analyze the uncertainty of the risk of investment income.

\subsection{Summary of the Literature Review and the Innovation}

The above literature review summarizes the definition and classification of M \& A financial risk, and provides different methods of risk measurement. This paper's innovation is to apply these fundamental theories in a real M\& A business case, and this case occurred in China capital market, the analysis process and result is helpful for companies going to operate a $\mathrm{M} \& \mathrm{~A}$ project and face the problem of analyzing financial risk.

\section{Analysis of the Financial Risk of Ping an Acquisition of Shanghai Jahwa}

\subsection{Case Introduction}

On September 7, 2011, Jahwa Group's shareholders Shanghai SASAC publicly listed to sell its holdings of $100 \%$ stake in the Group. On November 7, 2011, $100 \%$ stake of Jahwa Group that is the parent company of Shanghai Jahwa was obtained by Shanghai Pingpu Investment Co., Ltd. through the bid with 5.189 billion yuan. The latter is a wholly owned subsidiary of Ping An Trust's Ping An Innovation Capital.

Shanghai Jahwa is currently the leader in domestic chemical manufacturing, listed in the Shanghai Stock Exchange in 2001. In 2008, the Shanghai Municipal 
Government proposed that state-owned assets should withdraw from the general competition. The company of Ping An Group to participate in the acquisition is its holding subsidiary Ping An Trust and Investment Co., Ltd. The essence of the trust is the intermediary of the funds, and it collects the commission and the investment income from the client's funds and distributes the proceeds to the beneficiaries.

China Ping An Acquisition of Shanghai Jahwa is classified as private equity investment in Ping An Trust business. There are many success cases in private equity investment in Ping An, with the intention to continue to increase investment in this area. In recent years, domestic demand industries have achieved rapid growth due to economic recovery and policy promotion. Shanghai Jahwa is in a leading position in the domestic chemical industry, its unique corporate culture characteristics and the spirit of continuous innovation will make it grow more rapidly. After Ping An acquisition of Shanghai Jahwa, it is expected to obtain higher growth to obtain high investment income through internal growth and capital operation.

\subsection{Risk Assessment of Value Assessment}

There are many commonly used methods of enterprise value evaluation, in which the market law assessment is applicable to listed companies whose stocks can be traded freely in the capital market. The main evaluation indicators of the market method are price-earnings ratio, book value and market share, the most commonly used is the price-earnings ratio. This article will use the price-earnings ratio method to analyze Shanghai Jahwa's market value. Pricing-earnings ratio is used to roughly estimate the recovery period of the capital invested in the purchase of the stock.

$\mathrm{P} / \mathrm{E}$ equals price per share multiplies earnings per share. $\mathrm{P} / \mathrm{E}$ valuation bases on the assumption that investors expect future earnings to be on average. If investors believe that the future performance of enterprises will be better than the average level, then the enterprise price-earnings ratio can be higher in a reasonable range.

Enterprise valuation equals industry average price-earnings ratio multiplies corporate net profit. At the end of 2010, Shanghai Jahwa's P/E is about 57 times, with about 17 times higher than that of the daily manufacturing industry, indicating that the market is very promising about the development after restructuring.

According to the China $\mathrm{P} / \mathrm{E}$ Index website industry price-earnings ratio statistics, on September 15, 2011 the industry average price-earnings ratio of China's chemical industry listed companies was 40.73, then Shanghai Jahwa's relative value equals net profit multiplies industry average price-earnings ratio, that is $365,004,864$ yuan multiplies 40.73 , nearly 14.87 billion. Shanghai Jahwa's equity relative value held by Jahwa Group would be 14.87 billion yuan multiplies $29.24 \%$, that is 4.35 billion yuan.

In addition to other asset with a total of 0.1 billion yuan held by Shanghai 
Jahwa, and then the relative value of this acquisition is about 5.35 billion yuan, slightly higher than the actual purchase price of 5.190 billion yuan.

\subsection{Financing Risk Analysis}

China Ping An mainly rely on cash dividends during the holding period to make up for financing costs and related costs. The analysis of this section is: Recruiting fund filling equals increased cash flow after acquisition minus financing cash flow.

\subsubsection{Financing Costs}

The financing method that China Ping An acquires Jahwa is the use of its own funds and bank mergers and acquisitions loans.

The risk-free interest rate of its own funds is 3\% of China's one-year time deposit rate. At the beginning of 2012, the bank's five-year loan interest rate was about $6.8 \%$, because the loan interest had tax-saving effect on the $\mathrm{M} \& \mathrm{~A}$ enterprises. Chapter 3 mentions that the estimated income tax rate for Shanghai Jiawa is $21 \%$, and the cost of debt financing is: $6.8 \% \times(1 \%-21 \%) \times 50 \% \approx 5.37 \%$. At the end of 2012, Ping An Trust issued a trust fund financing belonging to Shanghai Jahwa equity pledged, and Ping An said that the financing was to repay the huge loans for mergers and acquisitions. In recent years, the investment rate of trust products is about $8 \%$.

According to the relevant policies of M \& A loans in China, M \& A loans can't exceed $50 \%$ of the purchase price. After signing the property rights contract, the investment in Pingpu has paid 50\% of its purchase price with its own funds. Assuming its own funds account for $50 \%$ of the acquisition price and $50 \%$ of the bank loan, the details of the financing cost of the acquisition are as Table 1.

The opportunity cost of its own funds does not require cash expenses; the income that trust fundraising pays for investors will cash at the end of the project, China Ping An does not need to pay in a short term. Therefore, the financing costs required to be paid during China Ping An holds the equity interest of Shanghai Jahwa are debt financing costs 107 million yuan.

\subsubsection{Increased Cash Flow after Acquisition}

The following Table 2 is the dividend program after ShanghaiJahwa is acquired. After calculation, Shanghai Jahwa has been four dividend programs after the

Table 1. China Ping An acquisition of Shanghai Jahwa financing costs.

\begin{tabular}{ccccc}
\hline Financing Channels & $\begin{array}{c}\text { Financing } \\
\text { Costs }\end{array}$ & $\begin{array}{c}\text { Financing } \\
\text { Ratio }\end{array}$ & $\begin{array}{c}\text { Amount of Financing } \\
(100 \text { million yuan })\end{array}$ & $\begin{array}{c}\text { Financing Costs } \\
(100 \text { million yuan })\end{array}$ \\
Own funds & $3 \%$ & $50 \%$ & 25.545 & 0.77 \\
Debt financing & $4.20 \%$ & $50 \%$ & 25.545 & 2.07 \\
Trust fundraising & $8 \%$ & $100 \%$ & 51.09 & 3.88 \\
Total & - & & & 2.04 \\
\hline
\end{tabular}

Source: Acquisition Announcement of Shanghai Jahwaon 2011/09/07. 
Table 2. Shanghai Jahwa dividend program after Acquisition.

\begin{tabular}{|c|c|c|c|c|c|c|}
\hline \multirow{2}{*}{$\begin{array}{l}\text { Announcement } \\
\text { Date }\end{array}$} & \multicolumn{3}{|c|}{ Dividend Program (per 10 shares) } & \multirow{2}{*}{$\begin{array}{c}\text { Total Cash Bonus } \\
\text { (yuan) }\end{array}$} & \multirow{2}{*}{ Shareholding Ratio } & \multirow{2}{*}{$\begin{array}{l}\text { Dividends Ping } \\
\text { An Gotten(yuan) }\end{array}$} \\
\hline & Bonus shares & Dividend (pre-tax) & Dividend (after tax) & & & \\
\hline $2015 / 5 / 12$ & 0 share & 6.2 yuan & 5.8 yuan & $389,972,692$ & 0.2714 & $105,838,589$ \\
\hline $2014 / 4 / 18$ & 0 share & 5.1 yuan & 4.85 yuan & $326,134,957$ & 0.2758 & $89,954,801$ \\
\hline $2013 / 5 / 21$ & 5 shares & 7 yuan & 6.3 yuan & $282,460,796$ & 0.2758 & $77,908,560$ \\
\hline $2012 / 7 / 9$ & 0 share & 4 yuan & 3.6 yuan & $161,409,960$ & 0.2923 & $47,180,131$ \\
\hline
\end{tabular}

Source: Shanghai Jahwa Dividend Program Announcement from 2012 to 2015.

acquisition, China Ping An obtains cash dividends with a total of 320,882,081 yuan, about 321 million yuan.

In addition to the financing costs mentioned above, China Ping An also needs to pay other costs directly related to $\mathrm{M} \& \mathrm{~A}$, including financial audit fees, consulting fees, and asset valuation fees. In accounting, these costs are not included in the cost of the merger, but included in the management costs.

In general, $\mathrm{M} \& \mathrm{~A}$ advisory fees account for an average of $0.5 \%$ to $1 \%$ of the value of the target company. The amount of this acquisition is 5.189 billion yuan. This article takes a discount ratio of $0.75 \%$, with a rough estimate that the consultation costs are about 38.32 million yuan. The total cost is 40 million yuan. Plus other costs. In addition to consulting fees, other related direct costs are estimated at 10 million yuan. Other direct costs forecast a total of 50 million yuan involved in the merger and acquisition.

As a result, the increased cash flow during China Ping An holds shares of Shanghai Jahua is: $3.21-0.5=271$ million yuan.

\subsubsection{Interest Repayment Deficit}

The financing cost of the $\mathrm{M} \& \mathrm{~A}$ is approximately 388 million yuan, and the financing cost for the holding period is about 107 million. At present, the increased cash flow 271 million yuan received by China Ping An during holding Shanghai Jahwa is higher than the total cost of financing 107 million yuan, but lower than the total cost of financing 388 million.

Therefore, without considering the date of interest payments, the risk of fund fulling of short-term financing of the acquisition is relatively low. But in the long run, there still exists a certain financing gap risk.

\subsection{Risk Analysis of Investment Income Uncertainty}

China Ping An promised not to transfer the ownership of Jahwa within 5 years in the detailed interest change contract, So China Ping An is not free to sell shares to cash within five years after the acquisition according to the rise in the price of Shanghai Jahwa's shares. The development trend of the daily chemical market and the future of the operation of Shanghai Jahwa are uncertain, so China Ping An investment income is uncertain.

Shanghai Jahwa was suspended on December 3, 2010 and resumed trading on November 15, 2011 after completion of the acquisition. The rise in share prices 
can bring book proceeds to China Ping An. Book income refers to the profits that have not cashed and formed actual interest in the securities investment process, that is, the market value of securities is higher than the purchase price difference.

China Ping An holding market value equals Shanghai Jahwa price per share multiplies total number of shares multiplies shareholding ratio. The Book profit equals target market value minus purchase price minus financing unpaid cost. Among them, the target market value equals China Ping An holding market value plus Jahwa Group other asset value. According to relevant information, in addition to Shanghai Jahwa, other assets of Jahwa group worth about 1 billion yuan. China Ping An holds all shares of Jahwa group, so in this acquisition, China Ping An income should include other assets value of Jahwa group in addition to Shanghai Jahwa.

The target market value minus the transaction price of 5.190 billion yuan and its own funds and trust fund-raising costs of 281 million yuan to get China Ping An book proceeds, the fluctuations shown in Figure 1. From the chart below, the book proceeds fluctuate from 3.67 billion yuan to 5.924 billion yuan after the acquisition of Shanghai Jahwa. The book proceeds fluctuation of China Ping An investing Shanghai Jahwa is relatively large, that is, there is uncertainty for China Ping An access to investment income in the future, so there is a certain financial risk.

\section{Conclusions, Suggestions and Limitation}

\subsection{Conclusions}

This study analyzes the risk of the target enterprise valuation, the risk of financing payment and the uncertainty of the investment income after the China Ping An acquisition of Shanghai Jahwa respectively. The results are as follows:

1) As for value assessment risk, this chapter uses the market method to assess the target enterprise value. According to the calculation results, the transaction

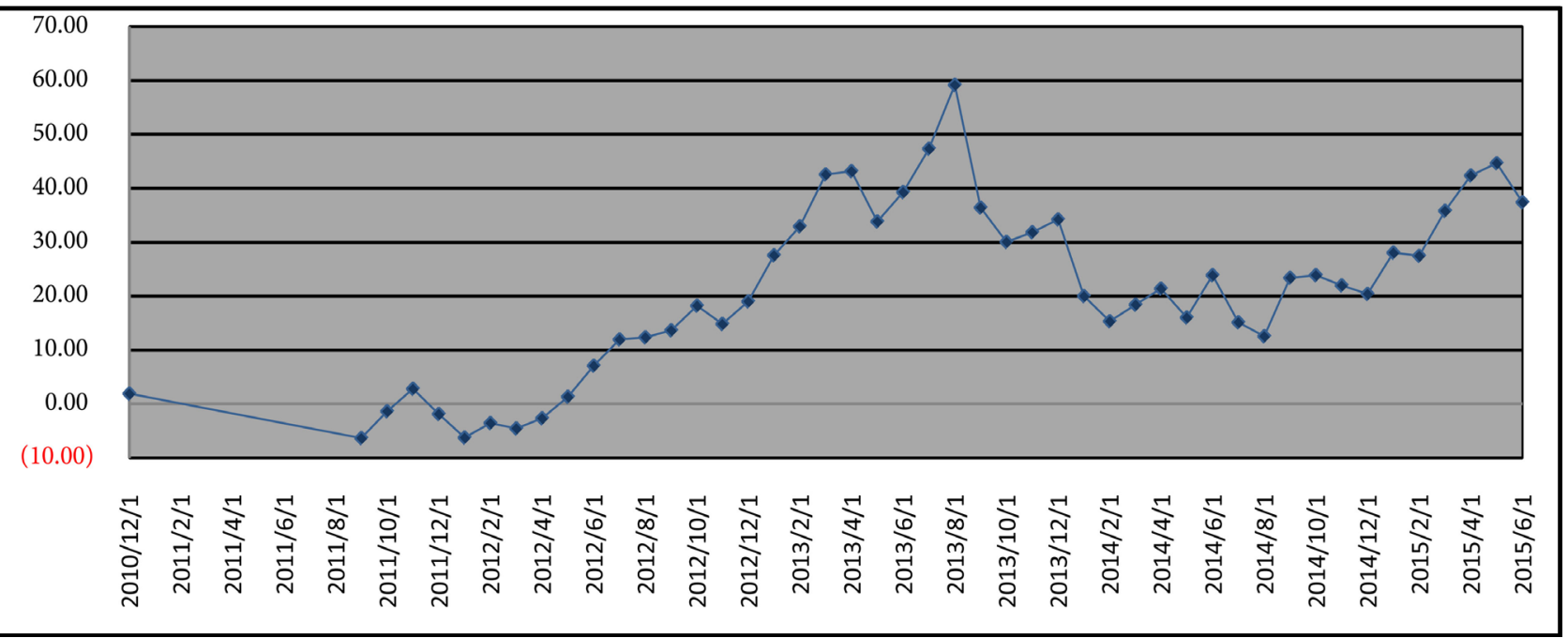

Figure 1. The book proceeds fluctuation after China Ping An acquisition of Shanghai Jahwa. 
price is relatively reasonable, the risk is small.

2) In terms of financing risk, the current cash flow increase in China's Ping An shares is higher than the financing cost, but it is lower than the total cost of financing. Therefore, the short-term funding gap in the acquisition financing is low, regardless of the interest payment date, but in the long run, there is still some financing risk in the acquisition.

3) As for investment income uncertainty risk, the price fluctuation of Shanghai Jahwa after the acquisition is obvious, and the uncertainty of China Ping An future investment income is greater.

\subsection{Suggestion}

In view of the above findings, this paper proposes the following risk control recommendations:

1) Adequate performance is used to price gambling methods. In essence, the gambling terms may be considered an option. China Ping An can set the minimum price to pay the purchase price in the pricing part of acquiring Shanghai Jahwa, and then consult with it about the performance requirements in the future. If the Shanghai Jahwa does not meet the agreed performance requirements, Ping An can require it to return a certain amount; If the Shanghai Jahwa reaches the agreed performance requirements, the Shanghai Jahwa can ask China Ping An additional investment.

2) Optimize the composition of corporate debt and the term structure, reasonable arrangement of the number of payment time. In general, the longer the payment period, the longer the time, but the more interest payments will be, the higher the cost will be. If the future business situation of the merged enterprise is not clear, it is possible to increase the payment period and extend the payment time. Although the corresponding payment costs will increase, taking into account the debt and cash flow gap of the merged company, this can still be able to reduce the pressure on enterprises to pay.

3) Track the supervision of operation of Jahwa, to assist the business development of the target party. The acquirer should continue to observe the operation of Shanghai Jahwa, and the supervisory approach includes requiring the target party to report on the operation regularly and the presence of the acquirer's directors. The acquirer should not only pay attention to the operation of the target side, but also concerned about the development of the industry and the relevant policies promulgated by the government.

\subsection{Limitation}

One of the limitations of this research is the lack of risk analysis in M \& A integration period. The future research needs to focus on the risk measurement and analysis after $\mathrm{M} \& \mathrm{~A}$. Another limitation is the chosen case's special characteristics. This $\mathrm{M} \& \mathrm{~A}$ case occurs in China Listed companies. Later research can explore different $\mathrm{M} \& \mathrm{~A}$ type, like acquisition of foreign target companies. 


\section{References}

[1] Healy, P.M., Palepu, K.G. and Ruback, R.S. (1992) Does Corporate Performance Improve After Mergers? Journal of Financial Economics, 31, 135-175.

[2] Jeffrey, C.H. (2000) Practical Guide to Mergers and Acquisitions. Economic Science Press, Beijing, 48-55.

[3] Deng, X.X. (2006) Financial Risk Analysis in Enterprise Group. M \& A. Master Thesis, University of Electronic Science and Technology, Chengdu, 5-9.

[4] Li, J.T. (2012) Financial Risk Analysis and Prevention of Enterprise M \& A. Journal of Economic Research, 3, 114-116.

[5] Hu, X.N. (2002) The Application of P/E Ratio in Enterprise Value Assessment. Journal of Capital University of Economics and Business, 1, 63-65.

[6] Song, X.S. (2007) The Choice of Pricing Method of Target Enterprise in Enterprise Merger and Acquisition. Journal of Shandong Vocational and Technical College, 5, 84-88.

[7] Ge, Q.B. (2012) The Value Assessment of the Target Enterprise in the Acquisition. China Collective Economy, 16, 101-102.

[8] Liu, B. (2012) A Comparative Study on Financing Cost of M \& A in China. Financial Perspective, 2, 141-145.

[9] Feng, Q. (1997) Loan Repayment Ratio and Interest Repayment Ratio Calculation Example and Meaning Analysis. Metallurgical Economy and Management, 2, 23-25.

[10] Zhang, J.R. (2003) Three Kinds of Income Views: Economic Benefits, Book Profit and Realized Revenue. Finance and Accounting Monthly, 11, 3-4.

Submit or recommend next manuscript to SCIRP and we will provide best service for you:

Accepting pre-submission inquiries through Email, Facebook, LinkedIn, Twitter, etc. A wide selection of journals (inclusive of 9 subjects, more than 200 journals)

Providing 24-hour high-quality service

User-friendly online submission system

Fair and swift peer-review system

Efficient typesetting and proofreading procedure

Display of the result of downloads and visits, as well as the number of cited articles

Maximum dissemination of your research work

Submit your manuscript at: http://papersubmission.scirp.org/

Or contact me@scirp.org 